\title{
$\frac{100}{\mathrm{LiT}}$ RPESS
}

\section{POSTPRAWDZIWA POLITYKA KLIMATYCZNA DONALDA TRUMPA}

\section{WSTĘP}

Na przestrzeni kilku ostatnich lat zainteresowanie zmianami klimatycznymi nabrało znacznej dynamiki zarówno w środowisku naukowym, jak i politycznym. Z jednej strony zdecydowana większość przedstawicieli świata nauki potwierdza fakt, że stopniowe ocieplenie klimatu, obserwowalne od końca XIX w., jest $\mathrm{w}$ dużej mierze uzależnione od gospodarki opartej na rosnącym zużyciu paliw kopalnych, z drugiej jednak - w retoryce polityków głównego nurtu niektórych państw pojawia się niepokojące lekceważenie, a nawet sprzeciw wobec naukowych prognoz i opinii na temat niestabilności ziemskiego klimatu. Takie tendencje wyraźnie znamionują antyklimatyczną politykę Donalda Trumpa. Podczas gdy w latach siedemdziesiatych i osiemdziesiatych XX w. Stany Zjednoczone przewodziły światu w ustanawianiu polityk i instytucji mających na celu ochronę naturalnego środowiska, to już w latach dziewięćdziesiątych następował widoczny regres $\mathrm{w}$ aktywności amerykańskiej administracji rządowej na rzecz wspierania wspólnej międzynarodowej polityki ekologicznej. Obecnie Stany Zjednoczone i Unia Europejska wydają się podążać już całkowicie rozbieżnymi ścieżkami w zakresie działań na rzecz ochrony środowiska. Przykładem tego jest niewątpliwie wycofanie się Ameryki pod wodzą czterdziestego piątego prezydenta z porozumienia klimatycznego w Paryżu.

Zasadniczym celem niniejszego artykułu jest próba ukazania kontrowersyjnych poglądów Donalda Trumpa na temat zmian klimatycznych w kontekście tzw. postprawdy politycznej, dla której fakty w kształtowaniu opinii publicznej mają mniejsze znaczenie niż odwoływanie się do emocji i osobistych przekonań. Coraz częściej pojawiająca się postprawdziwa narracja w świecie polityki staje się, niestety (!), wielkim zagrożeniem dla podstawowych warto-

* Adam Płachciak, Uniwersytet Ekonomiczny we Wrocławiu, adam.plachciak@ue.wroc.pl, https://orcid.org/0000-0001-7560-1538Z 
ści w dyskursie publicznym, takich jak prawda i prawdziwość. Obecnie globalną platformą uprawiania dyskursu publicznego są mass media, wśród których Internet jako narzędzie społecznej komunikacji odgrywa niewątpliwie zasadniczą rolę. Niemniej, w odróżnieniu od tradycyjnych mediów, Internet pozbawiony jest filtrującego informacje nadzoru. Często zdarza się tak, że prawda umieszczona w Sieci nie jest w stanie znieść konkurencji z postprawda, która jako zamiennik konkretnej rzeczywistości może być skutecznie fabrykowana dla osiagnięcia partykularnych, nierzadko społecznie szkodliwych, celów. Wykorzystywanie w polityce narracji odwołującej się do tzw. alternatywnych faktów jest bezsprzecznie zjawiskiem niosącym szereg zagrożeń dla przewidywalności działań politycznych liderów poszczególnych państw.

\section{PERSPEKTYWA BADAWCZA}

Sposób sprawowania władzy przez Trumpa i działania jego najbliższych doradców wpisują się niewątpliwie już do nowej epoki komunikacji politycznej, w której postprawdy stanowią istotę marketingu narracyjnego w świecie polityki. Dobitnym tego przykładem moga być wypowiedzi Kellyanne Conway, wysokiej rangi urzędniczki Białego Domu, w których, jak to sama nazywa, korzysta z ,interpretacji alternatywnych”, wyjaśniających prawdziwe tło zachodzacych faktów ${ }^{1}$. Znamienne jest to, że praktyki „koloryzowania” faktów nie były niczym nowym w działalności Trumpa. Pisał on o tym już w swojej książce The Art of the Deal w 1987 r.:

Jednej rzeczy nauczyłem się o prasie i dziennikarzach. Sa oni zawsze głodni dobrej historii, [...] chodzi o to, że jeśli jesteś trochę inny, [...] albo robisz rzeczy, które wymagają odwagi, a nawet sa kontrowersyjne, to prasa napisze o tobie. Zawsze działałem inaczej, nie mam nic przeciwko kontrowersjom, jeśli tylko wspierają moje ambitne interesy ${ }^{2}$.

Biorąc pod uwagę fakt, że wypowiedzi polityków nie zawsze są wewnętrznie spójne i nie do końca odzwierciedlają rzeczywistość, możemy dojść do wniosku, iż nie należy przywiązywać do nich większej uwagi. Stwierdzenie takie nie powinno być jednak aż tak oczywiste. Warto pamiętać, że na przestrzeni ostatnich lat różne informacje, także te z dziedziny tzw. faktów alternatywnych, umieszczone w wirtualnej przestrzeni wpłynęły w potężny sposób na sytuacje wewnętrzne poszczególnych państw, a także na relacje międzynarodowe.

Rozpoznanie znaczenia dyskursu politycznego Donalda Trumpa w kontekście postprawdy oraz jego możliwego wpływu na społeczną percepcję rzeczywistości wymaga wnikliwej i wieloaspektowej analizy działań komunikacyjnych stosowanych przez amerykańskiego prezydenta, wśród których niezwykle ważną rolę odgrywają Internet oraz współczesne media społecznościowe ${ }^{3}$.

\footnotetext{
1 Jackson (2017); Coscarelli (2017).

2 Trump, Schwartz (1987): 57. (Jeśli nie zaznaczono, wszystkie cytaty w tłumaczeniu autora).

${ }^{3}$ Gackowski et al. (2017); Ryoo, Bendle (2017): 244-266.
} 
W związku z tym podjęcie dalszych analiz będzie wymagało wyznaczenia określonego kierunku badań i doprecyzowania podstaw metodologicznych.

Dokonując próby ukazania poglądów Donalna Trumpa na temat zmian klimatycznych, szczególnie w perspektywie ich medialnej popularyzacji, zauważam istotny związek między produkcją i dystrybucją dyskursu politycznego amerykańskiego prezydenta a jego sposobem sprawowania władzy. „Każdy dyskurs - jak pisze Jerzy Szacki - jest zarazem systemem władzy, oznacza bowiem narzucenie pewnej liczbie ludzi jakiejś definicji prawdy i fałszu, dobra i zła, normalności i patologii, a więc i ujarzmienie tych, którzy granicę między nimi chcieliby przeprowadzić w jakiś inny sposób" ". Zakładając, że każdy dyskurs jest powiązany ze sferą władzy, pełni rolę pewnej ideologii i jest osadzony na określonym polu aksjologicznym, przyjmuję wypracowaną na gruncie krytycznej analizy dyskursu (w skrócie: KAD) perspektywę badawcza.

Krytyczna analiza dyskursu łączy w sobie podejście właściwe dla językoznawstwa oraz nauk społecznych i ma na celu ujawnianie ukrytych w dyskursie związków między tekstami, zdarzeniami i praktykami dyskursywnymi a szerszymi strukturami, relacjami oraz procesami społecznymi i kulturowymi. Przedmiotem tej optyki badań jakościowych jest m.in. wskazanie, jak owe teksty, zdarzenia i praktyki powstają i jak są ideologicznie kształtowane przez relacje władzy oraz jej walkę o dominację. Niemniej podejście krytyczne dyskursu w badaniach rzeczywistości społecznej budzi spore wątpliwości zarówno w obszarze teoretycznym, jak i metodologicznym. Szczególnie zwolennicy metod ilościowych zgłaszają swoje wątpliwości, twierdząc, że KAD należy do obszaru badań typowych dla metod „miękkich”, w których uzyskane wyniki badań sa zbyt ogólnikowe i trudno weryfikowalne ${ }^{5}$. Niektórzy uważaja, że KAD, ze względu na niejasność statusu metodologicznego, nie może być traktowana jako metoda. Niemniej postulowane zastrzeżenia mogą stać się również mocnymi stronami tej perspektywy badań ${ }^{6}$.

Nie wolno zapominać, że w badaniach jakościowych, w obszarze mocno związanym z polityką i polaryzacją społeczna, wymagany obiektywizm jest często trudny do uzyskania, a prezentowane wyniki badań wyraźnie odzwierciedlają subiektywne opinie badacza. KAD jest również świadomym narzędziem zmiany społecznej, pozwalajacym badaczowi jawnie stanać po stronie, którą on sam uzna za słuszną. Prezentowane wówczas przez niego analizy będą nie tylko opisem określonej rzeczywistości, ale też sposobem uświadamiania problemów społecznych oraz możliwością wyrażenia na ich temat swojej opinii i dążeniem do usprawniania działań instytucji społecznych ${ }^{7}$.

Mając na uwadze podjęcie badań na temat społecznego znaczenia dyskursu, należy doprecyzować jeszcze dwie ważne kwestie: (1) zdefiniować samo pojęcie dyskursu, (2) wybrać adekwatna perspektywę badawczą w obrębie

${ }^{4}$ Szacki (2992): 907.

${ }^{5}$ Kopytowska, Kumiega (2017): 177-180.

${ }^{6}$ Trutkowski (2004): 35.

${ }^{7}$ Dorczak (2019): 32. Szerzej na temat KAD zob. Fairclough (1989); Dijk (1991); Jäger (2001): 32-66; Wodak (1991): 65-83; Duszak (1998); Jabłońska (2006): 63-67. 
analizy dyskursu. Określenie znaczenia słowa „dyskurs” we współczesnym użyciu tego terminu napotyka pewne trudności. Często bowiem jest używane zamiennie z innymi terminami, takimi jak: język, komunikacja czy interakcja. Używane jest również w kontekście bardziej szczegółowym, tj. w odniesieniu do określonego obszaru użycia języka (np. dyskurs naukowy, dyskurs polityczny). Pojęcie dyskursu kojarzone jest też częściej z wypowiedzią niż z tekstem. Definiowane jest również jako rozmowa, dyskusja, przemówienie. Niemniej w podejściu typowym dla KAD zarówno tekst, jak i wypowiedź jest przedmiotem analizy dyskursu ${ }^{8}$.

W odniesieniu do wyboru perspektywy badawczej w obrębie analizy dyskursu wyodrębnia się trzy główne nurty badań zjawisk komunikacyjnych, tj. analizę lingwistyczna, socjologiczną i krytyczną. Nurt lingwistyczny koncentruje się na badaniach wokół tekstu, czy też nad analizą strukturalną dyskursu. Natomiast socjologiczna i krytyczna perspektywa uwzględnia procesualne i kontekstualne elementy dyskursu. Istotną rolę w tej orientacji, oprócz kwestii opisowo-wyjaśniającej, odgrywa płaszczyzna normatywna9 Ta też perspektywa jest punktem odniesienia podjętych niżej analiz.

\section{DENIALIZM KLIMATYCZNY TRUMPA}

Styl życia Donalda Trumpa oraz jego idea Ameryki jako państwa i jej roli $\mathrm{w}$ świecie wpisuja się niewątpliwie w najbardziej skrajne wzory politycznego myślenia i działania, które w żadnym stopniu nie przystają do wcześniejszych norm i wizji wypracowanych przez dotychczasowych prezydentów Stanów Zjednoczonych. Widoczne jest to szczególnie w jego polityce klimatycznej. Co prawda denializm amerykańskiego prezydenta w sprawie zmian klimatu wywołuje wiele kontrowersji i nieporozumień, nie jest on jednak odosobnionym głosem w świecie polityki ${ }^{10}$.

Niemniej negatywny stosunek Trumpa do kwestii zmian klimatu wpisuje się nie tylko do najbardziej skrajnych form denializmu klimatycznego ostatnich lat, ale funkcjonujac jako pewien rodzaj komunikatu w przestrzeni publicznej, staje się społecznie niebezpieczny. Umiejętność prezentowania przez amerykańskiego prezydenta trudnych spraw za pomocą nośnych ogólników i nierzadko skandalicznych newsów sprawiała to, że podawane przez niego informacje stawała się niezwykle przekonujące w obszarze mediów społecznościowych ${ }^{11}$. Szczególną rolę w tym przypadku odgrywał Twitter, na którym

${ }^{8}$ Duszak (1998): 14.

9 Jabłońska (2006): 56-57.

${ }^{10}$ Dunlap, McCright (2008): 26-35; Abbott (2009): 56.

${ }^{11}$ Wśród tematów, które Trump umieszcza na swoim Twitterze, pojawiają się takie, jak: polityka (44,09\%), media $(16,49 \%)$, bezpieczeństwo $(10,86 \%)$, gospodarka $(10,86 \%)$, zdrowie $(5,75 \%)$, społeczeństwo $(3,83 \%)$, prawo $(2,88 \%)$, kultura $(0,96 \%)$, życie prywatne $(0,96 \%)$, nauka $(0,64 \%)$, sport $(0,64 \%)$, armia $(0,32 \%)$, historia $(0,32 \%)$, inne $(0,96 \%)$ - zob. Gackowski Brylska, Patera et al. (2019): 43. 
Trump swobodnie dystrybuował swoje przekonania i opinie, oddziałując przez to $\mathrm{z}$ wielką łatwością na media i sferę publiczną ${ }^{12}$.

Ze względu na fakt, że aktywność Trumpa na Twitterze w dużym stopniu wyrażała sens i znaczenie prezentowanych przez niego poglądów, tę właśnie platformę społecznościową uznałem za podstawowe źródło informacji do przeprowadzenia podjętych poniżej analiz. Podczas doboru materiału badawczego kierowałem się faktem, że amerykański prezydent w swojej retoryce na temat zmian klimatycznych zwykle używa zwrotu „globalne ocieplenie”"13, toteż wpisujac takie hasło do wyszukiwarki znajdującej się na stronie Trump Twitter Archive, odnalazłem 110 interesujacych mnie wpisów ${ }^{14}$. Zostały one opublikowane w okresie między październikiem 2011 a lutym 2019 r.

\section{Analiza językowych cech wypowiedzi Trumpa}

Analiza językowa wypowiedzi Trumpa na temat zmian klimatycznych pozwala zauważyć, że amerykański prezydent używa typowego dla swojej retoryki pojęcia „globalne ocieplenie” (global warming), określając je często innymi zwrotami, takimi jak: „kosztowna mistyfikacja”, „MISTYFIKACJA”, „totalna mistyfikacja”, „całkowicie sterowane przedsięwzięcie”, „prawdziwa GŁUPOTA”, „fikcja”, „mit”, „bzdura”, „zmanipulowane i bazujace na fałszywej nauce dane”, „wielokrotnie udowodnione kłamstwo”. Pisane wielkimi literami pojedyncze wyrazy lub całe ich frazy moga świadczyć o tym, że prezydent pragnie w ten sposób podkreślić ważne dla siebie treści lub też wyrazić na ich temat określone emocje. Grafizacja tekstów elektronicznych - jak zauważa Jan Grzenia - „stwarza nowe sposoby przekazywania informacji i nowe sposoby przekonywania. Należy mieć na uwadze, iż — być może — wkrótce będziemy mówić o semantyce tekstu elektronicznego. $\mathrm{Z}$ pewnością już dziś możemy mówić o jego retoryce" ${ }^{15}$. Takich też i innych zabiegów retorycznych w swoich tweetach używa niewątpliwie Trump ${ }^{16}$. Większość zamieszczonych wpisów z listy 110 analizowanych tekstów jest autorstwa samego prezydenta (90\%), ale wśród nich znajdują się też takie, których treść została zaciagnięta ze źródeł zewnętrznych (10\%), są to m.in.: strony internetowe, czasopisma, profile informacyjne oraz cytaty pochodzące bezpośrednio z innego profilu na Twitterze.

12 Za: Gackowski, Brylska, Patera (2019): 6.

13 Na podstawie analizy treści stworzonych przez Trumpa tweetów można wnioskować, że pojęcia „zmiany klimatyczne” i „globalne ocieplenie” amerykański prezydent całkowicie myli. Świadczyć może o tym następująca jego wypowiedź (@realDonaldTrump/4.05.2012/): „In the 1920's people were warried about global cooling - it never happened. Now it is global warming. Give me a break!” („W latach dwudziestych ludzie byli zatroskani nadejściem globalnego ochłodzenia - to się nigdy nie stało. Teraz mówi się o globalnym ociepleniu. Dajcie z tym spokój!”).

14 Zob. Trump Tweeter Archive <http//www.trumptwitterarchive.com> [dostęp: 5.05.2020].

15 Grzenia (2004): 25.

${ }^{16}$ Gackowski, Brylska, Patera et al. (2019): 88. 
W wypowiedziach na temat zmian klimatycznych Trump artykułuje swoje przekonania w sposób nieformalny. Zdaniem Johna McWhortera - językoznawcy z Columbia University - amerykański prezydent trafia przez to do gustu milionów swoich rodaków. Nieformalność, jak twierdzi McWhorter, to „marka Amerykanów”, pewien styl ich życia. Pomimo iż niektórzy amerykańscy prezydenci korzystali z takiej formy artykulacji swoich przekonań, w przypadku Trumpa nieformalność to cecha jego osobowości ${ }^{17}$. Przykładem tego mogą być następujące stwierdzenia:

(@realDonaldTrump/23.11.2013/) [...] what the hell is going with GLOBAL WARMING? ([...] o co chodzi do diabła z tym GLOBALNYM OCIEPLENIEM).

(@realDonaldTrump/25.03.2013/) They changed the name from "global warming" [...]

(Oni zmienili nazwę z GLOBALNEGO OCIEPLENIA [...]);

The Chinese talk of climate change and carbon footprint

(Chińczycy mówią o zmianach klimatycznych i śladzie węglowym [...]).

(@realDonaldTrump/24.04.2013/) The concept of global warming was created by [...] Chinese (Koncepcja globalnego ocieplenia [...] została stworzona przez Chińczyków).

[...] they really do believe the American public is stupid

([...] oni naprawdę wierza, że Amerykanie są głupcami).

Treść takich wypowiedzi trafia niewątpliwie do wyobraźni przeciętnych obywateli. W przekonaniu hiszpańskiej lingwistki Laury Alba-Juez komunikat przekazany w tekście nie zawsze w odbiorze adresatów odzwierciedla jego oryginalne znaczenie, stanowi często subiektywne wyobrażenie, które ludzie sami do jego treści modelowo dobudowuja ${ }^{18}$. Trump jest niezwykle skuteczny w kreowaniu takiego obrazu zmian klimatycznych.

Struktura językowa tweetów Trumpa jest raczej prosta i łatwo zrozumiała dla każdego potencjalnego odbiorcy komunikatów umieszczanych na tej platformie społecznościowej. Amerykański prezydent wyraża swoje opinie na temat zmian klimatycznych/ocieplenia klimatu w sposób mało skomplikowany. Unika zdań złożonych, co stanowi bardzo charakterystyczny styl jego publicznych wypowiedzi w ogóle. Pojęcia, których używa, nie stwarzają problemów $\mathrm{w}$ ich zrozumieniu. Są to w zdecydowanej większości jedno- lub dwusylabowe słowa, rzadziej pojawiają się trzy- i czterosylabowe zwroty i terminy. W swoich wypowiedziach Trump uwielbia stawiać znaki zapytania oraz wykrzykniki:

(@realDonaldTrump/29.02.2014/) It's late in July and it is really cold outside in New York. Where the hell is GLOBAL WARMING??? We need some fast! It's now CLIMATE CHANGE (Jest późny lipiec, a w Nowym Jorku mamy naprawdę zimo. Gdzie do diabła jest GLOBALNE OCIEPLENIE??? Potrzebujemy nieco przyspieszenia! To obecne ZMIANY KLIMATU).

Cechą znamionująca język amerykańskiego prezydenta są również występujące w nim pojęcia i zwroty, za pomocą których forsuje on w sposób nieznoszący sprzeciwu osobiste poglądy i przekonania, atakując tym samym swoich

17 McWhorter (2017).

18 Alba-Juez (2009). 
politycznych przeciwników. Wśród nich znajdują się m.in. takie określenia, jak: „marnotrawstwo”, „bezmyślność”, „zło” „fałszywe informacje”, fałszywa nauka". Wyraźnie widoczne jest to w wypowiedziach, w których krytykuje on m.in. Baracka Obamę:

(@realDonaldTrump/18.05.2013/) Reckless! Why is Barack Obama wasting over \$70 Billion on 'climate change activities?' Will he ever learn?

(Lekkomyślność! Dlaczego Barack Obama marnotrawi ponad 70 miliardów dolarów na działania związane ze „zmianą klimatyczną”? Czy on się kiedykolwiek czegoś nauczy?).

(@realDonaldTrump/30.03.2013/) Waste! With a \$16T debt and \$1T budget deficit, Barack Obama is sending $\$ 770 M$ overseas "to fight global warming"

(Marnotrawstwo! Z długiem w wysokości 16 trylionów dolarów i deficytem budżetowym w wysokości tryliona dolarów Barack Obama wysyła za granicę 770 milionów euro „na walkę z globalnym ociepleniem").

Warto zauważyć, że wpisy te zostały zarejestrowane jeszcze na długo przed objęciem przez Trumpa prezydentury. Jednak ich ton zasadniczo nie zmienił się aż do zakończenia jego kadencji prezydenckiej.

\section{Potencjalne źródła inspiracji denializmu klimatycznego Trumpa}

Wskazanie źródeł dystrybucji cytowanych treści ma niewątpliwie istotne znaczenie, gdyż w pewnym sensie może to sugerować, jakich informacji Trump poszukuje i jakie moga go zasadniczo motywać do prezentacji swoich poglądów i przekonań. Wśród autorów, których amerykański prezydent chętnie cytuje, i do poglądów, do których często nawiązuje, znajdują się zasadniczo publicyści piszacy w takich czasopismach i portalach internetowych, jak: „The New York Post”, „The Wall Street Journal”, „Forbes”, „The Register”, CnsNews.com czy ClimateDep.com. Większość przywoływanych treści posiada charakter wyraźnie dziennikarski, nierzadko o wysoce wątpliwej naukowo argumentacji. Przykładem może być opublikowany już w 2011 r. następujący wpis:

(@realDonaldTrump/30.11.2011/): Newly released e-mails prove that scientists have manipulated data on globar warming. The data is unreliable

(Nowe wiadomości e-mailowe potwierdzają fakt, że naukowcy zmanipulowali informacje dotyczące globalnego ocieplenia. Dane są niewiarygodne).

Trump odwołuje się tutaj do artykułu Jamesa Delingpole'a z „The Wall Street Journal”, w którym jego autor pisze m.in.: „W ubiegłym tygodniu do sieci wypłynęło ponad 5000 plików pochodzących z prywatnej korespondencji e-mailowej kilku światowej sławy naukowców zajmujących się zmianami klimatycznymi. Podobnie jak w przypadku pierwszego "climategate« z 2009 r., najnowsze informacje wskazują na to, że czołówka uczonych z branży wyraźnie fałszuje dane, aby zastraszyć i wyciszyć swoich oponentów. Osobiście jednak wyrażaja znacznie mniejsze przekonanie co do wiarygodności antropogenicznej teorii zmian klimatycznych, niż przedstawiają to $\mathrm{w}$ swoich na- 
ukowych publikacjach"19. Podobny ton argumentacji Trump utrzymuje w kolejnym tweecie, pisząc:

(@realDonaldTrump/28.03.2012/): Global warming has been proven to be a canard repeatedly over and over again

(Wielokrotnie udowodniono już to, że zmiany klimatyczne to przekręt).

Amerykański prezydent, formułując w ten sposób swoje przekonanie, bazuje na artykule profesora Williama Happera, który powołując się na swoje badania i obserwacje, stwierdza wprost: „W przewidywaniach dotyczących zmian klimatycznych łatwo jest postawić błędne diagnozy. Jesteśmy stale bombardowani ostrzeżeniami o możliwości zaistnienia okropnych rzeczy, które mogą wydarzyć się w wyniku nadmiernego wykorzystywania paliw kopalnych. Niemniej te złowieszcze przewidywania sa oparte na modelach stworzonych na podstawie matematycznych obliczeń komputerowych. Ważne jest jednak to, aby odróżnić, jak zachowuje się faktycznie klimat, od tego, co przewidują modele matematyczne. Zaobserwowanie zmian klimatycznych jako reakcji na zwiększanie się stężenia $\mathrm{CO}_{2}$ nie zawsze jest zgodne z przewidywaniem modelu"20.

W swojej retoryce antyklimatycznej Trump używa często argumentów podważających hipotezę, iż zmienność i nieprzewidywalność zjawisk pogodowych są rezultatem globalnego ocieplenia. Przykładem może być następujący wpis:

(@realDonaldTrump/5.11.2012/): Great article in the@NewYorkPost by Ben Garrett_"Do not Blame Sunday for Global Warming"

(Wspaniały artykuł Benna Garretta w @NewYorkPost „Nie obwiniaj huraganu Sunday za globalne ocieplenie").

W rekomendowanym przez amerykańskiego prezydenta artykule czytamy m.in.: „Ekstremalne fenomeny pogodowe nękały ludzkość od zarania jej dziejów. Zapisy historyczne potwierdzają fakt, że siła huraganu, który ostatnio dotknął Nowy Jork, znamionowała podobne zjawiska pogodowe już XIII w. [...] Niewątpliwie Sunday, po Irene z września zeszłego roku, był z kolei drugim co do wielkości tak potężnym huraganem, który niemalże całkowicie sparaliżował życie mieszkańców Nowego Jorku, ale częstotliwość występowania porównywalnych żywiołów w tym rejonie miała miejsce już w połowie lat 50. ubiegłego wieku. [...] Można więc przyjąć, że zjawiska te maja swój bezpośredni związek z naturalnymi cyklami Matki Ziemi. Nie ma to zaś nic wspólnego z globalnym ociepleniem" ${ }^{21}$.

W podobny sposób Tramp formułuje też treść kolejnego tweetu:

(@realDonaldTrump/17.09.2014/): Great article on so-called climate change, formally known as global warming

(Wspaniały artykuł na temat tzw. zmiany klimatycznej, oficjalnie określanej globalnym ociepleniem).

\footnotetext{
19 Delingpole (2011).

20 Happer (2012).

21 Garrett (2012).
} 
Podstawą tego wpisu był artykuł Toma Harrisa i Boba Cartera z „The New York Post”, w którym krytykują oni m.in. serię nagrań filmowych Leonarda DiCaprio poświęconych kryzysowi klimatycznemu. Warto pamiętać, że amerykański aktor, producent filmowy, a także znany działacz ekologiczny przygotował te materiały w związku z oenzetowskim szczytem klimatycznym, który odbył się w Nowym Jorku we wrześniu 2014 r. Po przeczytaniu tego artykułu ma się jednak wrażenie, że jego autorzy bazują jedynie na swoich subiektywnych odczuciach i spostrzeżeniach, w których przeważa wysoce emocjonalna narracja. Świadczyć może o tym chociażby następująca wypowiedź: „DiCaprio jest aktorem, a nie naukowcem; w nagranym przez niego filmie jest wiele sensacji i błędów. Inni fantaści żyjący urojeniami o zmianach klimatycznych, pomimo swego naukowego doświadczenia, mają jednak znacznie mniej wyobraźni” 22 . Pomijając całą resztę innych autorytetów, których amerykański prezydent przywołuje w swoich tweetach, nietrudno jest zauważyć, jakie jest źródło jego wypowiedzi na wzmiankowany temat.

\section{Ideologiczny wymiar denializmu klimatycznego Trumpa}

Denializm klimatyczny Trumpa jest niewątpliwie istotnym elementem forsowanej przez niego ideologii gospodarczego nacjonalizmu. Jeszcze długo przed objęciem urzędu głowy państwa pisał on:

(@realDonaldTrump/05.11.2012/): We can't destroy the competitiveness of our factories in order to prepare for nonexistent global warming. China is thrilled with us!

(Nie możemy zniszczyć konkurencyjności naszych fabryk, aby podejmować działania na rzecz zapobiegania nieistniejącego globalnego ocieplenia. Chiny tylko na to czekaja!).

Politykę gospodarczego nacjonalizmu Donalda Trumpa można zasadniczo streścić w często powtarzanym przez niego zdaniu: „Make America Great Again!” („Uczyńmy Amerykę Znowu Potężną!”). W tym stwierdzeniu da się usłyszeć echo wyborczego hasła Ronalda Reagana z lat osiemdziesiatych. Amerykańscy wyborcy w tym czasie, po serii porażek Cartera, oczekiwali nowego powiewu w polityce i życiu gospodarczym. Wówczas Reagan przy dużym poparciu swoich wyborców deklarował, że Amerykę uczyni a shining city on a hill (,świecącym miastem na górze”). Jednak między stwierdzeniami obu prezydentów istnieje kolosalna różnica. Wsłuchując się w deklaracje Reagana na temat tego, co Ameryka mogłaby wnieść dla bezpieczeństwa świata, marzył on niewątpliwie o kraju, który is not turned inward, but outward - towards others (,nie jest zwrócony do wewnątrz, ale skierowany na zewnątrz ku innym”). Natomiast Trump obiecywał postawić Amerykę na pierwszym miejscu, jednocześnie domagając się szacunku ze strony przywódców wolnego świata oraz traktowania jego kraju jako całkowicie niezależnego od ekonomii globalnego rynku ${ }^{23}$. W programie gospodarczym Donalda Trumpa znajduje się wiele chwytliwych obietnic, takich jak: niższe podatki, likwidacja zbędnej

${ }^{22}$ Harris, Carter (2014).

23 Trump's World. The New Nationalism (2016). 
biurokracji, bardziej korzystne warunki dla krajowej przedsiębiorczości itp. Lecz są też w nich niepokojące zapowiedzi zerwania międzynarodowych umów handlowych, zwłaszcza z krajami Ameryki Południowej, czy też groźby wojny gospodarczej z Chinami. Trudno nie dojść do wniosku, że wspólna polityka klimatyczna napotka również na silny opór ze strony prezydenta Stanów Zjednoczonych.

Faktycznie, tak też się stało. Trump po objęciu władzy w Białym Domu rozpoczął proces likwidacji amerykańskich zobowiązań wobec międzynarodowych porozumień klimatycznych. W pierwszej kolejności podjął decyzję o przeorganizowaniu dotychczasowych urzędów odpowiedzialnych za ochronę środowiska. Niewątpliwie otworzyło mu to drogę do przeforsowania nowych kandydatur na stanowiska szefów tych instytucji. W większości jednak osoby te już wcześniej deklarowały swój negatywny stosunek do kwestii związanych ze zmianami klimatycznymi. W tym gromie znalazł się m.in. Scott Pruitt, któremu powierzono funkcję szefa administracji Environmental Protection Agency (EPA). Znany był z publicznych wystapień jako zdecydowany przeciwnik globalnego ocieplenia. Wielokrotnie też protestował wobec polityki ograniczania emisji dwutlenku węgla ${ }^{24}$. Było to całkowicie sprzeczne $\mathrm{z}$ oświadczeniami EPA, które bazowały na miarodajnych badaniach naukowych przynajmniej już od lat dziewięćdziesiątych ubiegłego wieku. Innym klimatycznym denialistą był Rick Perry, który objął stanowisko Sekretarza ds. Energetyki (Energy Secretary). Był on wcześniej głównym pomysłodawcą likwidacji tego ministerstwa $^{25}$. Szefem Rady Białego Domu ds. Jakości Środowiska (the White House Council on Environmental Quality) została Kathleen Hartnett White, która w 2016 r. publicznie oświadczyła, że wiara w istnienie globalnego ocieplenia

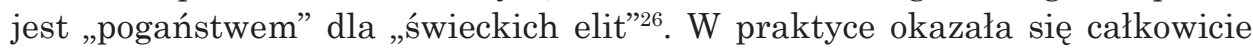
niekompetentna w spawach polityki środowiskowej, co ostatecznie zaważyło na usunięciu jej z piastowanego urzędu. Szefem administracji NASA - organizacji, która w ostatnich dziesięcioleciach odegrała czołową rolę w prognozowaniu zjawisk związanych ze zmianami klimatycznymi - został kolejny sceptyk globalnego ocieplenia, James Bridenstine.

W następstwie przeprowadzonych zmian administracja Trumpa podjęła decyzję o uchyleniu Planu Czystej Energii (Clean Power Plan) oraz zliberalizowaniu regulacji emisji spalin komunikacyjnych (Auto Emission Rule). Wprowadzono unormowania, które skutkowały drastycznym cięciem środków budżetowych przeznaczanych na działalność instytucji i organizacji ekologicznych. W rezultacie ofiarami tych działań stały się m.in. takie organizacje, jak: Agencja Ochrony Środowiska (EPA), Narodowa Służba Oceaniczna i Atmosferyczna (NOAA), Organizacja Nardów Zjednoczonych (UN), Narodowa Agencja Aeronautyki i Przestrzeni Kosmicznej (NASA). Natomiast ich beneficjentami zostały firmy, które ubiegały się o koncesje na wydobycie węgla i ropy naftowej. W rezultacie tej polityki wznowiono budowę rurociagów

\footnotetext{
24 DiChristopher (2017).

25 Mufson, Sullivan (2017).

${ }^{26}$ Kaczynski (2017).
} 
Keystone XL oraz Dakota Access Pipeline, których realizację wstrzymał rząd Baracka Obamy ${ }^{27}$.

Biorąc pod uwagę fakt, że poparcie dla działań klimatycznych w społeczeństwie amerykańskim oscyluje na poziomie $65-75 \%$, to szkody, jakie Trump wyrządził swoją polityka antyklimatyczna, są nieobliczalne. Nie tylko niepokojąca jest jego retoryka, w której argumenty, jakich używa, są zwykłą mieszaniną osobistych przekonań, wymyślonych faktów oraz teorii spiskowych. Problemem pozostaje również to, że lekceważenie międzynarodowych porozumień klimatycznych przez rząd tak dużego kraju, jakim są Stany Zjednoczone, nie zachęca przywódców innych państw do poważnego respektowania swoich zobowiązań ograniczenia emisji gazów cieplarnianych. Inną kwestią pozostaje również wpływ niekontrolowanych informacji negujących globalne ocieplenie na poszerzający się krag klimatycznych denialistów kwestionujących w tym zakresie osiagnięcia naukowe. Rodzi to też obawy samych naukowców przed polityką ograniczania dotacji na prowadzone przez nich badania.

\section{ZAKOŃCZENIE}

Analiza wypowiedzi oraz działań politycznych Trumpa w obszarze tematu zmian klimatycznych/globalnego ocieplenia napotyka wiele trudności. Jest w nich sporo ładunku emocjonalnego oraz niespójności logicznych i rzeczowych. Wśród źródeł inspirujących dystrybuowane przez niego antyklimatyczne poglądy i przekonania znajdują się głównie materiały z czasopism i portali internetowych autorów o wyraźnej republikańskiej proweniencji, negujących antropogeniczną genezę zmian ziemskiego klimatu. Antyklimatyczne poglądy Trumpa mają wyraźnie ładunek wartościujący oraz ideologiczny. Wpisują się one w promowaną przez niego koncepcję gospodarczego nacjonalizmu, wspierającego m.in. amerykański sektor energetyczny oparty na paliwach kopalnych. Biorac pod uwagę uporczywe powtarzanie Trumpa o nieistnieniu globalnego ocieplenia, amerykański prezydent wyraźnie izolował Stany Zjednoczone na arenie międzynarodowej od możliwości wspólnych działań na rzecz poprawy ziemskiego klimatu. Taki też dyskurs, szczególnie w obszarze mediów społecznościowych, przekłada się również na pozbawiony bezpiecznego nadzoru przepływ informacji mających decydujące znaczenie dla tworzenia się określonych typów poglądów, przekonań, preferencji. Warto pamiętać, że wygrane wybory Trumpa z Hillary Clinton w dużej mierze polegały na skutecznym przyciagnięciu uwagi często niezdecydowanych i niezaangażowanych politycznie obywateli będacych jednocześnie użytkownikami mediów społecznościowych ${ }^{28}$.

${ }^{27}$ Remarks by the President in TransCanada Keystone XL Pipeline Announcement. The White House (Mar. 24, 2017). <https://www.whitehouse.gov/briefings-statements/remarks-presidenttranscanada-keystone-xl-pipeline-announcement/> [dostęp: 6.06.2020]; Remarks by President Trump on Regulatory Relief. The White House (Jun. 9, 2017). <https://www.whitehouse.gov/ briefings-statements/remarks-president-trump-regulatory-relief $>$ [dostęp: 6.06.2020].

28 Williams (2017): 27-211; Ryoo, Bendle (2017): 244-266. 
Już w pierwszym roku urzędowania prezydenta Trumpa stało się to oczywiste, że jego administracja będzie dążyła do zinstytucjonalizowania ideologii wspierającej denializm klimatyczny. Poprzez obsadzenie ważnych stanowisk rządowych licznymi przeciwnikami działań na rzecz poprawy klimatu Trump dążył do odwrócenia proklimatycznej i prośrodowiskowej polityki Baracka Obamy. Widoczne to było już w treści jego wczesnych tweetów z lat 20122013. Obsesyjnie antyklimatyczna retoryka owych wpisów pozostała aż do zakończenia jego kadencji. Poddając krytycznej analizie denializm klimatyczny Donalda Trumpa, należy założyć, że mamy raczej do czynienia z dyskursem, gdzie debatę publiczna oraz fakty naukowe zastępuje propaganda. Wypowiedzi amerykańskiego prezydenta na temat „ocieplenia klimatu” przypominaja raczej sądy „o mojej prawdzie” lub „naszej prawdzie”, często też określanej mianem „postprawdy”. Postprawdziwa retoryka w dyskursie politycznym Trumpa nie posiada charakteru ani absolutnego, ani uniwersalnego. Miara wyznawanej przez niego „prawdy” nie jest empirycznie potwierdzona wiedza. Liczą się raczej treści, których atrybutem jest docierająca do masowego adresata „atrakcyjność” i „sensacyjność”. Specyficznie budowana narracja Trumpa na Twitterze, zasadniczo oparta na „mniemaniach” i „gdybaniach”, stanowi ważny, ale też i niebezpieczny, element tzw. miękkiej siły (soft power), pozwalającej na kształtowanie preferencji poszczególnych jednostek czy też większych zbiorowości bez konieczności użycia siły i przemocy.

Zrozumiały może być fakt, że fałszowanie rzeczywistości w polityce było znane od zawsze. Pisał o tym już Machiavelli, z tym że pojawiajace się wówczas w dyskursie politycznym kłamstwo było wyraźnie przeciwstawiane prawdzie, a tych, których na nim przyłapano, skutecznie usuwano ze sfery publicznej. Dziś prawda straciła swoją wartość i też mało kogo interesuje. Czy jednak budowanie relacji na podstawie tzw. alternatywnych faktów, tworzenie swego własnego wizerunku na zmyślonych historiach, uprawianie polityki w wirtualnej rzeczywistości, nierzadko stworzonej przez opłacanych „trolli”, nie jest drogą donikąd? Warto przy tej okazji pamiętać, że główny rywal Trumpa, demokrata Joe Biden, co prawda obiecywał w swoim programie wyborczym zwrot w stronę czystej energii i powrotu do paryskiego porozumienia klimatycznego, niemniej na liście wyborczych priorytetów zajmowały one miejsce m.in. za takimi obietnicami, jak rozwój gospodarczy, służba zdrowia, odwołania do Sądu Najwyższego czy też walka z pandemią.

Abbott, T. (2009). Battlelines. Melbourne: Melbourne University Publishing.

Alba-Juez, L. (2009). Perspectives on Discourse Analysis. Theory and Practice. Newcastle upon Tyne: Cambridge Scholars Publishing.

Coscarelli, J. (2017). Kellyanne Conway Admits "Blowing Green Massacre" Error. The New York Times 03.02.2017. <https://www.nytimes.com> [dostęp: 20.04.2020].

Czyżewski, M. (2009). Między panoptyzmem i „rządnomyślnością” - uwagi o kulturze naszych czasów. Kultura Współczesna 2(60): 83-95.

Delingpole, J. (2011). Climategate 2.0: A New Batch of Leaked Emails Again Shows Some Leading Scientists Trying to Smear Opponents. The Wall Street Journal Nov.11.2011. <http://t.co/DdW3Hsvn> [dostęp: 11.05.2020]. 
DiChristopher, T. (2017). EPA Chief Scott Pruitt Says Carbon Dioxide is not a Primary Contributor to Global Warming. <https:/www.cnbc.com/2017/03/09/epa-chief-scott-pruitt.html> [dostęp: 4.06.2020].

Dijk van, A. T. (1991). Racism and the Press. London-New York: Routledge.

Dorczak, R. (2017). Wokół reform edukacji z 2017 roku. Krytyczna Analiza Dyskursu (Monografie i Studia Instytutu Spraw Publicznych Uniwersytetu Jagiellońskiego). Kraków.

Dunlap, R.E., McCright, A.M. (2008). A widening gap: republican and democratic views on climate change. Environment: Science and Policy for Sustainable Development 50(5): 26-35.

Duszak, A. (1998). Tekst, dyskurs, komunikacja. Warszawa: Wydawnictwo PWN.

Garrett, B. (2012). Do not blame Sunday for global warming. The New York Post Nov. 2, 2012. <http://t.co/o2VHHPOa> [dostęp: 11.5.2020].

Grzenia, J. (2004). Strona WWW jako strona dialogowa, [w:] M. Kmita (red.). Dialog a nowe media. Katowice: Wydawnictwo Uniwersytetu Śląskiego.

Happer, W. (2012). Global warming models are wrong again: the observed response of the climate to more CO2 is not in good agreement with predictions. The Wall Street Journal Mar. 27, 2012, <http://t.co/RK1UoS8e> [dostęp: 11.05.2020].

Harris, T., Carter, B. (2014). Leo vs. science: vanishing evidence for climate change. The New York Post Sep. 17, 2014. <http://t.co/fEYAhQ7lGB [dostęp: 11.05.2020].

Jabłońska, B. (2006). Krytyczna analiza dyskursu: refleksje teoretyczno-metodologiczne. Przegląd Socjologii Jakościowej 2(1): 53-67.

Jackson, D. (2017). Conway backs Spicer's version of "facts". USA Today 3.01.2017. <https://eu.usatoday.com> [dostęp: 28.04.2020].

Jäger, S. (2001). Discourse and knowledge: theoretical and methodological aspects of a critical discourse and dispositive analysis, [w:] R. Wodak, M. Meyer (eds.). Methods of Critical Discourse Analysis. London: Sage Publications: 32-62.

Fairclough, N. (1989). Language and Power. London: Longman Group Ltd.

Gackowski, T., Brylska, K., Patera, M., Galan, K., Piórecka, K., Kowalczyk, M., Kwiatkowska, A., Rajchert, M., Białek, A., Sztyber, M., Kalinowska, M. (2019). Ćwierkający Donald Trump. Czym Jest Tweeter dla użytkowników, dziennikarzy i prezydenta USA. Od analizy dyskursu po badania okulograficzne. Toruń: Wydawnictwo Adam Marszałek.

Kaczynski, A. (2017). Trump pick for top environmental post called belief in global warming a "kind of paganism'. <https://edition.cnn.com/2017/10/19/politics/kfile-kathleen-hartnett-white-paganism/index.html> [dostęp: 4.06.2020].

Kopytowska, M., Kumiega, Ł. (2017). Krytyczna analiza dyskursu: konteksty, problemy, kierunki rozwoju, [w:] M. Czyżewski, M. Otrocki, T. Piekot, J. Stachowiak (red.), Analiza dyskursu publicznego. Przegląd metod i perspektyw badawczych. Warszawa: Wydawnictwo Akademickie Sedno: $177-180$.

McWhorter, J. (2017). How to listen to Donald Trump every day for years. The New York Times Jan. 21, 2017. <https://www.nytimes.com/2017/01/21/opinion/sunday/how-to-listen-to-donald-trump-every-day-for-years.html> [dostęp: 20.05.2020].

Mufson, S., Sullivan, S. (2017). Rick Perry expresses 'regret' for pledging to abolish Energy Department. The Washington Post Jan. 19, 2017. <https:/www.washingtonpost.com/business/ economy> [dostęp: 4.06.2020].

Ryoo, J., Bendle, N. (2017). Understanding the social media strategies of U.S. primary candidates. Journal of Political Marketing 16(3/4): 244-266.

Szacki, J. (2002). Historia myśli socjologicznej. Warszawa: Wydawnictwo Naukowe PWN.

Trump, D.J., Schwartz, T. (1987). Trump: The Art of the Deal. New York: Ballantine Books.

Trump's World. The New Nationalism (2016). The Economist Nov. 19, 2016. <https://www.economist.com> [dostęp: 11.05.2020].

Trutkowski, C. (2004). Wybór czy konieczność - o potrzebie wykorzystania analizy dyskursu w socjologii. Kultura i Społeczeństwo 48(1): 53-67.

Williams, Ch.W. (2017). Introduction: social media, political marketing and the 2016 U.S. election. Journal of Political Marketing 16(3/4): 207-211.

Wodak, R. (1991). Turning the tables: antisemitic discourse in post-war Austria. Discourse \& Society 2(1): 65-83. 


\section{DONALD TRUMP'S POST-TRUTH CLIMATE POLICY}

\section{Sum mary}

The aim of the article is to present Donald Trump's climate denialism as an example of political post-truth, where the facts are of less importance than referring to emotions and personal convictions. Trump's convictions on 'global warming', particularly in their media popularization, played a key role in the production and distribution of political discourse by the former American president and the way he expressed his power. The research perspective is essentially developed on the basis of critical discourse analysis.

Keywords: climate change; post-truth; Trump; critical discourse analyses; JEL codes: Q54, H41, Q01 